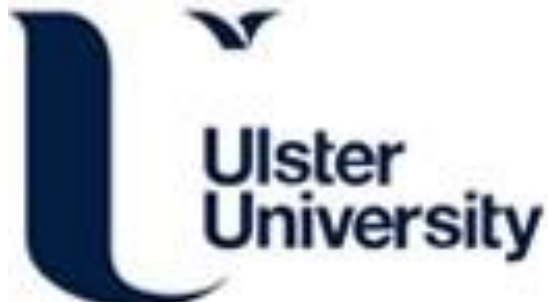

\section{With a little help from my fans: the transformative role of the consumer in music co- production}

Gamble, J. (2018). With a little help from my fans: the transformative role of the consumer in music coproduction. Production Planning \& Control, 29(10), 826-844. https://doi.org/10.1080/09537287.2018.1478148

Link to publication record in Ulster University Research Portal

\section{Published in:}

Production Planning \& Control

Publication Status:

Published online: 01/08/2018

DOI:

10.1080/09537287.2018.1478148

\section{Document Version}

Author Accepted version

\section{General rights}

Copyright for the publications made accessible via Ulster University's Research Portal is retained by the author(s) and / or other copyright owners and it is a condition of accessing these publications that users recognise and abide by the legal requirements associated with these rights.

\section{Take down policy}

The Research Portal is Ulster University's institutional repository that provides access to Ulster's research outputs. Every effort has been made to ensure that content in the Research Portal does not infringe any person's rights, or applicable UK laws. If you discover content in the Research Portal that you believe breaches copyright or violates any law, please contact pure-support@ulster.ac.uk. 
With a little help from my fans: the transformative role of the consumer in music co-production Jordan Robert Gamble, PhD

This paper examines how the transformative role of the consumer in co-production is affecting key stakeholders within the music industry. The study explores the changing consumer role in coproduction, how it is affecting content quality, the implications for music artists and record labels and how they are approaching (and should approach) co-production. The research methodology consists of a three-stage interview design of fifty-two in-depth, semi-structured interviews with senior members of music organisations (including artist managers and major labels). An inductive, datadriven four-phase constant comparison analysis technique is used to analyse the data. The findings contribute to the co-production research domain by offering new insights from a music industry context and presenting new theoretical models for how co-production is affecting industry stakeholders. Implications for industry, policy and future research are also provided.

Keywords: co-production; co-creation; music industry; music artists; record labels 


\section{Introduction}

This paper explores the phenomenon of co-production from the perspective of how it affects key players within the recorded and live sectors of the music industry. The concept of co-production is inextricably linked with the domain of value co-creation (Vargo and Lusch 2008), in which some scholars propose a positive relationship where a company provides resources to enable the consumer's value creation process, whilst becoming a value co-creator (Löfberg et al. 2015). However, others maintain that coproduction does not exist within value co-creation but rather is opposed to it on account of the significant potential for co-producing consumers to influence the value system in negative ways (Lengnick-Hall 1996). Ultimately, co-production is differentiated by its definition as 'participation in the development of the core offering itself' (Lusch and Vargo 2006, p. 284). The current study therefore focuses on co-production, as opposed to value co-creation, through its exploration of how core music industry offerings (i.e. the music itself and other music-related content) are co-produced between music artists and the consumers. The paper will address consumer-driven co-production activities such as mash-ups, bootlegs and re-mixes, in addition to industry-driven activities such as interactive creation platforms, music/lyric writing incentives and opportunities for non-music content design, for instance album cover submissions.

The theoretical and managerial significance of co-production should also be considered. The concept of co-production of content with the end-consumers, in which co-development is aligned with unique consumer requisites, is considered a driver of innovation in the management literature (Gosling et al. 2015). For instance, Cova and Dalli (2008) suggest that the firm-based integration of consumers in the production of market value is vital in terms of maintaining competitive advantage through innovation. Other potential organisational implications of integrating end-consumer contributions into the production process include the enhancement of radical innovation capabilities (Lettl et al. 2006; Lettl et al. 2008; Prügl and Schreier 2006). A quantitative study by Auh et al. (2007) concluded that, in the context of consumer participation in co-production activities, the organisational benefits include reduced costs, stronger perceptions of customisation, enhanced personal interfaces with the consumers, increases in loyalty and, ultimately, greater customer spending intentions. Echeverri and Skalen (2011) argue that co-production is actualised when the consumer and the producer draw on compatible features correlated with the practice of mutual help, thus suggesting that the benefits are in fact contingent on those of the consumer. They acknowledge the commonly-held view that co-production occurs when consumers 'get what they pay for', although they also speculate that the opposite may in fact be true and that the failure to deliver the core service might actually represent the driving force behind coproduction.

Despite the theoretical and managerial significance of co-production within organisational contexts, there has been a notable lack of research to date that has addressed how this increasingly evident phenomenon is impacting on stakeholders operating within specific industries and sectors. The current gaps in research and knowledge include: firm implications of consumers experimenting with 
physical products created by the firm (Berthon et al. 2007); the ways in which user communities impact upon innovation processes within the organisation (Di Gangi and Wasko 2009; Romero and Molina 2011); the distinct stakeholder perceptions of the effects of these communities on the co-production of experiences (Rowley et al. 2007); and how firms can engage with - or even employ - user communities for co-production of innovation (Rowley et al. 2007; Jeppesen and Frederiksen 2006). Moreover, Gebauer et al. (2013) recently stated that there is still insufficient knowledge surrounding effective conflict management for co-production projects in various contexts; how much should firms that initiate co-production rely on community self-management; and how to develop strategies for stakeholders who decline to participate in co-production activities, despite awareness in the media. Ultimately, the managerial implications of consumer participation in co-production processes and activities are still not well defined (Ind et al. 2013).

The current paper seeks to address these shortcomings by empirically exploring the management effects of co-production from the context of the music industry, in which co-production of creative content is becoming increasingly commonplace on account of Creative Commons licenses (Cammaerts et al. 2013). Notably, the phenomenon of music content co-production - both driven by the consumers through unofficial remixes and mash-ups as well as by the industry through marketingrelated creative initiatives - has been acknowledged by various music industry news publications (see Anixter 2015; Thomas 2012), yet has not received much academic attention to date. In exploring coproduction within this particular context, this paper will address the contemporary issues facing the music industry in the digital age. For instance, the most recent International Federation of the Phonographic Industry (IFPI) report (2017) states that, despite recent growth after several years of decline, the industry faces enduring challenges relating to the devaluing of music content, legislative violations, unfair licensing practices and copyright infringement. Furthermore, disruptive innovations continue to create infrastructural shifts at the industry level, compounded with the involuntary redefining of business models at the firm level (Gamble et al. 2017). This is as various traditional industry firms seek alternative approaches to managing the distribution of digital music and meeting the changing (and increasingly demanding) needs of the consumer (Mulligan 2014; Wikström 2012). A recent Nielsen report (2017) on the music industry concluded that 'the rapid changes in technology and distribution channels are changing the way we discover and engage with content'. The focus of this paper is how this consumer engagement in creative content has managerial implications for the music industry stakeholders of independent music artists and major record labels.

The remainder of this paper is structured as follows. Section 2 will provide a review of the literature that discusses co-production of activities in the music industry and will discuss any theoretical development within this domain. Section 3 will outline the methodological approach taken for the empirical data collection. Section 4 will present the results and discussion of the empirical data. Section 5 will then draw conclusions and discuss implications for practitioners, policy-makers and future research. 


\section{Literature review}

\subsection{Content co-production within the music industry}

Although the technology-driven rise of user-generated content in the digital age has been well documented in various industries and sectors (Burmann 2010; Shao 2009), only in the past several years have innovations in the music industry facilitated interactive platforms that are affecting the coproduction of music itself (Stensaeth 2013; Gamble and Gilmore 2013). According to a recent news media article on the Innovation Excellence website (Anixter 2015, p. 1), one such innovative platform is LoopLabs, described as a 'free, collaborative cloud based music studio that would let anyone, regardless of technical skills or ability, easily make, share and discover music anywhere.'

Mulligan (2011, p. 2) discusses user contributions to music production by stating that a "natural extension of fan engagement is to bring fans into the creative process. This is Fan-Fuelled Creativity. Turning to fans for creative input is new and unfamiliar ground for many'. He later proposes three distinct objectives for this fan-fuelled activity: a) creativity; b) engagement and c) marketing, with the first referring specifically to user contributions to music production. He then elaborates on the 'creativity' aspect by discussing the range of creation variations available to consumers; these include mash-ups, bootlegs, ringtones and remixing tracks. The key element that Mulligan emphasises is the need for embedded functionality into the music formats. This aspect of functionality and creating the unique experience can actually be seen in a documented case of a British music group who have released 'stems' from one of their songs for the music consumers to remix (Jones 2012). They even added a further innovative element to the concept by allowing the consumers to sell their remixes and keep both the profits and the intellectual property (IP) rights to the remix (although the artists will still receive publishing royalties). Despite the above suggestions in the literature of a repositioning of the traditional consumer role on account of the supply from the industry and the demand from the consumers, few empirical studies have explored this phenomenon. This oversight is surprising, given that this transitional role of the consumer into the producer sphere within any industry context can lead to significant boundary implications for both the joint sphere and interaction platforms (Grönroos and Voima 2013). The extent to which new technological drivers are profoundly affecting the ability of music consumers to make this transition, as is arguably the case in non-music industries (Gyrd-Jones and Kornum 2013), also remains unclear. What we do know is that, even from an organisational perspective, it is vital to understand the consumer role in the co-production process - regardless of industry - as it is the mutually influential relationship between the consumer and the producer that is the pre-requisite for co-production to occur (Grönroos and Voima 2013). Therefore, the aspect of how the consumer role within the music industry is changing due to co-production will be investigated in the current study, as part of the overall exploration of how co-production is affecting the industry and its inherent stakeholders.

Anderson (2009, p. 73) considered music consumer preferences towards producer roles in his seminal book 'The Longer Long Tail' in which he theorised about the opportunistic aspect of the endless 
long tail of the demand curve for entertainment industries. He summarised the emerging role of the consumer-producer by stating that 'When the tools of production are available to everyone, everyone becomes a producer'. This statement highlights concerns regarding the implications for the musical outputs in terms of quality when the traditional roles of 'producer' and 'consumer' are broken down and 'anyone could become a producer'. Plé et al. (2010) advance this discussion by providing a case study for a corporation called MyMajorCompany.com, which they claim utilises what they refer to as a 'customer-integrated business model', in which the consumer is directly involved in the music production process - much in the same way as the proposed 'Consumartist' business model by Bourreau et al. (2012). However, they elaborate further on the new roles of the consumer within the music production process - as an investor, artist 'tester', marketer and/or generator of network externalities. These statements advance the above discussion by not only highlighting the expansive role of the consumer, but importantly raising the question of the implications of consumer contributions on the music output. In non-musical contexts, it has been suggested that the newly-founded consumer role of co-designer and co-developer can have a positive influence to the point that the consumer is considered a resource in the firm's production process (Grönroos and Voima 2013). However, the extent to which this is the case within the music industry remains unclear and there is a notable dearth of empirical findings in relation to this important issue. Therefore, the aspect of implications of music co-production on content quality will be explored in the current study.

\subsection{Theoretical development}

There is limited but interesting theoretical discussion in the academic literature around the concept of co-production of music and how it affects industry stakeholders. Bourreau et al (2012) have theorised the construction of new digital music business models that specifically relate to consumer involvement in the production process. One such model features social networking and recommendation aspects to integrate with the various players within the production channel. Another model depicts a blurring of the boundaries between professionals, occasional producers and amateurs in the music production chain. Modification and re-use is now available to everyone who is perceived as a potential collaborator or contributor. Bourreau et al. (2012) adopted a quantitative methodology of economic analysis and survey data in their aforementioned study of how radical innovations are affecting music industry business models, yet the aspect of co-production was not developed nor empirically investigated. The reality is that the current academic literature lacks findings on how co-production may lead to negative - as well as positive - ramifications for the music industry at the firm/stakeholder level. In the nonmusic industry literature, it is suggested that co-production affects the producer in a myriad of ways including financial and marketing gain (Gebauer et al. 2013), creative insights (Ind et al. 2013) and new market-quality products (Oliveira and von Hippel 2011). Interestingly, the limited music industry research on co-production has tended to concentrate on the negative industry ramifications, such as reputational harm for the artists and music offerings that digress from the artist's known 'sound' 
(Jarvenpaa and Lang 2011). Therefore, the aspect of how music co-production is truly affecting content producers (i.e. the artists and their representative labels) - both positively and negatively - will be explored in the current study.

The aspect of a music industry co-production model has been adhered to as part of a coproduction of marketing continuum proposed by Gamble and Gilmore (2013), which involved usergenerated content from both musical and non-musical contexts. The significance of both co-production of marketing and music content within the industry is also emphasised by Mulligan (2011, p. 2) in his industry report, in which he discusses how 'Forums, social networks and other such communication tools have brought artists and their fans much closer together than was ever possible [...] A natural extension of fan engagement is to bring fans into the creative process.' This statement is influential in two ways. Firstly, it accentuates how the effects of co-production of music content on not only production-related innovation processes of industry stakeholders but also marketing-related and finance-related should be considered. Secondly, it raises the significant aspect of whether or not key stakeholders such as artists and labels recognise the value in co-production and if they are prepared to adapt their own business strategies to incorporate its integration. Grönroos and Voima (2013) argue that co-production in general only truly works when both parties are willing participants and influence each other through mutually beneficial interactions. In non-music industries, producers have been advised to develop strategies that integrate co-production more closely with their own product development, as a means to augment their stakeholder benefits (see Henkel and von Hippel 2005). However, others concede that IP owners may have insufficient incentives to license co-production content due to high costs and complexities (Harhoff et al. 2003). Unfortunately, despite the proliferation of co-production instances throughout the music industry, it is still largely unknown how the key stakeholders of artists and labels are approaching the prospect of embracing and even driving co-production as part of their current and future organisational strategies. Therefore, the aspect of how artists and labels are currently approaching co-production, and what future strategic approaches they should develop, will be explored in the current study.

\section{Research methodology}

\subsection{Overview}

As a result of the decision to incorporate an interpretive methodological approach due to the exploratory nature of the study, a qualitative methodology was adopted. This was designed in order to fulfil the intrinsic requirements of high-quality, in-depth investigation of how co-production in the music industry is affecting the appointed stakeholders. In taking a qualitative approach, the research study was able to ascertain motivations, perceptions and beliefs (Milena et al. 2008), whilst giving order to these meanings as a now-conventional attribute of management research (Johnson et al. 2007).

\subsection{Research method}


In terms of the chosen qualitative data collection method, as this study specifically sought to explore music co-production from an industry perspective at the organisational level, this was indicative of interview-based data collection from industry representatives (as opposed to the consumers). The focus group method would not have been the most appropriate as this tends to be more closely correlated with social research involving members of the public. The use of in-depth, face-to-face interviews is well established in the management research domain as a qualitative research method (Adebanjo et al. 2015). It is adopted for the purposes of gathering expert viewpoints on a specific research topic in order to acquire insights into the individual's comprehension of a phenomenon (Milena et al. 2008). It was therefore decided that one-on-one interviews would be conducted, with several interview stages, in order to facilitate comparative analysis of different stakeholder views and potential follow-up interviewing. On account of the exploratory nature of the study and the prospect of covering new research ground, the first stage consisted of broad data collection from an array of music industry representatives in order to contextualise the data from distinct industry viewpoints and approaches. The next stage then involved specified and focused data collection by speaking directly to the stakeholder groups of artists and major labels. The final stage entailed consolidation of data collection via followup interviews with key interviewees from the first stage. This approach of contextualising the research from distinct stakeholder perspectives fulfils the 'transferability' criterion of Guba's (1981) construct for qualitative research trustworthiness.

Regarding the population of interviewee candidates, this study - as consistent with many other music industry studies - was not geographically constrained due to the global access to music through social and technological channels (Izvercian and Alina Seran 2013; Soriano et al. 2008; Power and Hallencreutz 2007; Choi and Burnes 2013; Gamble and Gilmore 2013; Chaney 2012; Warr and Goode 2011). Accordingly, candidates from potentially any English-speaking country were deemed appropriate if they either held a senior management position within their company or significant knowledge or experience of music co-production. The decision to interview both autonomous industry experts (including freelance researchers and entrepreneurs) and company representatives (mostly CEOs and senior managers) was taken in order to augment the richness of the data. In line with the global sampling nature of the study, interviews were ultimately conducted with candidates from different continents including Europe, Africa, Australia and North America. A scoping exercise was conducted to identify possible interview candidates for the three interview stages. A range of scoping techniques was adopted, including search engine keyword searches, LinkedIn networking and additional searches in online databases and portals. As a result of this, eighty-eight potential Stage One interview candidates were identified and their contact details were documented. These candidates can be broadly delineated into three categories: senior managers of music industry firms that offer services to facilitate coproduction; industry professionals or academics who research or write on the phenomena of music coproduction; and other individuals who have several year's industry experience in the field of music coproduction. This three-category approach ensured that an accurate depiction of the co-production 
phenomenon in the music industry was presented, thus adhering to the 'credibility' criterion of Guba's (1981) construct for qualitative research trustworthiness.

\subsection{Data collection}

A total of 52 interviews were conducted across the three interview stages, resulting in a total of 2,363 minutes of interview data and 461 pages of interview transcripts. Stage One of the interview design entailed interviews with thirty-four music industry authorities with an expertise of co-production. This represented a significantly high response rate of $39 \%$ of the eighty-eight candidates that were initially identified, using a range of scoping techniques including search engine keyword searches such as "cocreation", "co-production", "user innovation", "prosumer" and "lead user" - each combined with "music" or "music industry". Additionally, LinkedIn networking was used, as well as searches in online databases of music industry contacts such as GINGIO, Musician's Atlas, The Unsigned Guide and Music Business Registry. The interviews resulted in 1,800 minutes of interview data (with an average duration of 53 minutes per interview) and 339 pages of interview transcripts.

Stage Two provided more focused and in-depth study by conducting interviews with five representatives from each of two relevant industry stakeholder groups (independent artists, represented by their managers, and major record labels) based on issues that emerged from the Stage One interview data. Artist managers were interviewed on behalf of the artists as they possess sufficient industry knowledge and experience to adequately generate high quality interview data from the questions. They also have a stake in the findings of this study because, according to Ramírez (2005), they need the artists' innovativeness, authenticity and style for their own market success. A second smaller scoping exercise was conducted specifically for the two identified Stage Two interview candidate groups. LinkedIn networking was used extensively in order to establish networking connections with industry professionals associated with either artist management companies or the three major record labels. This scoping exercise resulted in the identification of forty-eight artist manager candidates and thirty-three major label candidates. Stage Two resulted in 348 minutes of interview data (with an average duration of 35 minutes per interview) and 57 pages of interview transcripts.

Stage Three consisted of follow-up questions with eight select interviewees from Stage One, in order to establish final insights that reflected on initial statements as well as the responses from the Stage Two interviewees. The candidates were chosen based on the quality of the interview data produced from their Stage One interview statements, the significance of themes that emerged from this data and the relevance of the Stage Two interviewee responses to these statements and themes. No scoping exercise was necessary as all of the potential candidates were previously identified and contacted for the Stage One interviews. This stage resulted in 215 minutes of interview data (with an average duration of 27 minutes per interview) and 65 pages of interview transcripts. A complete breakdown of the interviewees from the three interview stages is provided in Appendix A, and the full list of interview questions is presented in Appendix B. 


\subsection{Data analysis}

In order to formulate a data analysis framework for the three-stage interview data, a number of aspects were considered such as the analysis approach, the coding approach and the analysis technique. In terms of analysis approaches, Knox (2003) describes a deductive approach as one in which a hypothesis or theory is developed and then tested using an arbitrary research strategy, whereas an inductive approach involves the collection of data followed by analysis which informs theoretical development. Due to the exploratory nature of this study, compounded with the dearth of knowledge surrounding the domain of co-production within the music industry, an inductive approach was adopted. In terms of a coding approach, DeCuir-Gumby et al. (2011) describe theory-driven as well as structural approaches - in which the analysis codes are derived from the project's research goals or questions. However, the most applicable approach to the current study was a data-driven one, in which DeCuir-Gumby et al. describe how the codes emerge from the raw interview data - thus apropos to an exploratory, theory-driven study. Lastly, in terms of analysis techniques, seven distinct techniques are proposed and detailed by Leech and Onwuegbuzie (2007) in their influential paper. The most pertinent and applicable technique to the current study was a constant comparison analysis technique, in which underlying themes and subthemes are identified over several stages of qualitative data collection. The data for this study was analysed through the software NVivo 9, which is generally acknowledged as one of the leading qualitative data analysis packages in the management field (Edhlund 2011; O'Neill 2013).

On account of the above methodological decisions, an inductive, data-driven, four-phase constant comparison analysis technique was conceived and implemented for the current study. The four phases are outlined below; through the rigour of these analyses, this study takes steps towards fulfilling the 'dependability' criterion of Guba's (1981) construct for qualitative research trustworthiness.

Phase One: Category Analysis. This phase involved the reduction of raw interview data (DeCuirGunby et al. 2011); the creation of thematic categories (Edhlund 2011) in order to provide aspects to describe, explain and/or compare (Ryan and Bernard 2003); the establishment of links between data and results (Elo and Kyngäs 2008); and the writing up of category findings.

Phase Two: Thematic Analysis. This phase consisted of reading through the category data from Phase One; abstracting any obvious themes (Edhlund 2011); establishing links between the data and results (Elo and Kyngäs 2008); modifying the links as new categories emerge inductively (Zhang and Wildemuth 2009); writing up the category / theme findings; comparing themes across data sources (DeCuir-Gunby et al. 2011); and rechecking coding consistency (Zhang and Wildemuth 2009).

Phase Three: Sub-thematic Analysis. This phase involved iterative reading through the category data from Phase One and thematic data from Phase Two in order to: ensure the quality of the codes (DeCuir-Gunby et al. 2011); identify and code sub-themes; combine or organise the sub-themes into smaller numbers of categories (Hsieh and Shannon 2005) and hierarchical structures (O'Neill 2013); establish any links between the data and results (Elo and Kyngäs 2008); write up the category / thematic 
/ sub-thematic findings; compare the themes / sub-themes across data sources (DeCuir-Gunby et al. 2011); and recheck coding consistency (Zhang and Wildemuth 2009).

Phase Four: Reliability Analysis. This phase consisted of: summarising the links between the data and results (Polit and Beck 2004); assessing the reliability via cross-referencing of data against the characteristics of participants (Elo and Kyngäs 2008) or the triangulation of data sources (Hsieh and Shannon 2005); writing up the findings; achieving a balance between authorial text and authentic citations (Elo and Kyngäs 2008); relating the findings back to the literature; and drawing logical conclusions from the findings.

Table 1 below presents the categories, themes and sub-themes that emerged as a result of the four-phase analyses. The next section will now present the findings and discussion which emanated from these analyses of the interview data. In demonstrating how these findings emerged from the data and not author predispositions, this study adheres to the 'confirmability' criterion of Guba's (1981) construct for qualitative research trustworthiness.

[Table 1 here]

\section{Results and discussion}

This section will present and analyse the themes and sub-themes that were raised in the interviews in relation to co-production activities such as the co-production of music content and the co-production of music-related content (for example, album artwork, fan-made music videos or consumer-made artist merchandise). The findings will also be discussed in comparison to previous extant research. The interviewee names have been anonymised into identifiers featuring the interview stage number (e.g. S1, S2 or S3) followed by two randomly assigned letters.

\subsection{The changing role of the consumer in music production}

The transformational role of the consumer in music industry production processes was discussed across the three interview stages. In the Stage One interviews, three of the interviewees raised and considered the prospect of consumers becoming music artists themselves through their co-production activities. S1FG stated that this would have disruptive yet positive implications for the hierarchical industry structure as it would 'invigorate the music industry from the ground up.' Grönroos and Voima (2013, pp. 141-142) state that 'The customer may also become active and cross the boundary into the provider sphere. This moves the boundaries of the joint sphere and creates a broader interaction platform'. Our findings advance this statement by demonstrating how, in the music industry, the boundaries of this value sphere extend upwards through the hierarchical industry levels, and the ramifications exceed mere interactions. We now know that these new consumer-artist hybrid entrants to the industry may bring in entirely new perspectives from their dual roles and may influence the industry in fresh and paradigmshifting ways. For S1MR, co-production, whether through remixing or original content creation, 
signified 'another route for people to get into the music business'. He also stated that the technology drivers for co-production have also effectively resulted in a 'lower barrier to entry to create music that sounds good enough to be distributed'. These statements feed into those by S1FG by suggesting that technology enablers for distribution quality are providing opportunities for music fans of variable artistic talent to enter the industry and contribute to the creative offerings without enduring technological disadvantages. From a non-music context, Gyrd-Jones and Kornum (2013, p. 1485) comment that 'the increasing penetration of Internet amongst consumers and the emergence of Web 2.0 technologies are profoundly affecting the ability of consumers to engage in co-creational activities.' Our findings build upon this statement by showing how, within music industry contexts, it is the combination of lower entry barriers and higher distribution quality resulting from technological advances that represents the key enabler for these new consumer-artists. Thus, we now understand that this may facilitate a fundamental shift in the way industry stakeholders manage their relationships with artists and musical outputs, through the democratisation of previously hierarchical roles within the industry.

Another theme that was raised independently by several of the interviewees throughout the three-stage interview process related to how, through proactive co-production of campaigns from artists or labels, the consumer role can convert into a non-musical content co-producer. For example, in the Stage Two interviews with the major record labels, S2FB highlighted the potential for co-production relating not to the music itself but subsidiary activities such as product design. He stated that 'we've actually worked with super fans to help create the ideal product and then produced something which looks like what they've delivered.' Chaney $(2012$, p. 49) has commented that 'co-production by consumers is also realized in a more tangible way. In the case of the music industry, the consumers themselves create support for the artists e.g. designing covers'. Our findings advance this statement by demonstrating how the music consumers can utilise their non-music talents to assist in the early production phase of related content for artists, then professional designers can finalise the high-end details to create an approximation of the fans' contribution, whilst maintaining sufficiently high quality for sales.

Some of the other interviewees believed that consumer involvement in visual co-production could extend beyond merely cover design. For instance, in his Stage One interview, S1CS - who had substantial experience researching and writing about music industry co-production - cited numerous examples of video or social media campaigns that now feature visual creative contributions from the consumers and he advocated their opportunistic properties on account of the adaptability of visual media. Two of the major label interviewees also discussed the aspect of video media contributions by describing their experiments into allowing consumers to collaboratively create official music videos for their signed artists. Henkel and von Hippel (2005, p. 18) suggest that firms more generally can 'enhance their benefits from user innovation by developing strategies that integrate user innovation more closely (and consciously) with their own product development efforts'. Our findings contextualise this 
statement by highlighting the significance of adaptability as a key constituent of music industry firm strategies - both in terms of the media and shifting label control paradigms - as a key driver for facilitating innovation growth in music co-production.

In the Stage One interviews, S1EP suggested that the rise in co-production in the live sector will force the major labels to adapt their business model to embrace - and eventually profit from consumer recordings of live events. He stated that the labels 'do not like people videotaping live concerts. [...] They're going to have to embrace it eventually and figure out a way to use it to their advantage.' This viewpoint provides insights into the involuntary innovation implications of coproduction for this stakeholder. Regarding artist responses, S1EP also expressed that some artists have adhered to an even more negative approach to fan-created audio/video recordings of live events through the creation of preventative apps to discourage fans from posting 'bouncy bad audio/video' on YouTube. Brown (2014, p. 60) advises that a 'willingness for fans to use peer production to create live albums via reciprocal relationships with artists could lead to a new generation of even more economical live albums and films'. We advocate this statement, although it appears that, in the short term at least, there is still a substantial amount of resistance from both the content creators and representatives to coproduction. This is arguably on account of a lack of knowledge into the associated industry benefits of entertaining the preferences of innovative and creative consumers.

A summary of the key findings from the above discussion is presented in Figure 1 below, with highlighted boxes indicating the key insights that are derived from multiple interview sources, and arrows indicating the direction of influence between constructs.

[Figure 1 here]

\subsection{Quality of content from music co-production}

S1PS suggested in his interview that content co-production would suffer from mediocrity and a lack of ingenuity on account of being an amalgamation of multiple ideas. He commented that 'it's going to be everybody's idea put together and will just end up in the middle of the road. You never get a Salvador Dali from a crowd-source.' S1MK - whose band experimented with limited co-production - supported this mediocrity argument by advising that their fans occasionally send in song lyrics but 'they're just not good enough really' to be of use to the artists. S1TH also suggested negative implications for bands affiliated with certain brands due to the perceived content dilution of incorporating co-production into their creative process. Grönroos and Voima (2013, p. 140) express that 'the customer acts as a coproducer (co-designer, co-developer) in the firm's production process, such that the customer is a resource in the firm's production process.' Our findings demonstrate that this is not invariably the case within the music industry due to the talent factor and brand perceptions. This issue of perceived content dilution provides an insight into the future challenges facing artists as music co-production becomes increasingly commonplace throughout the industry. It shows that, although the democratisation of 
music creation may be essentially restructuring the traditional hierarchies and paving the way for interesting hybrid outputs with the consumers, the perceived inferiority of music co-produced with the fans represents a potential prejudice that may ensure a slow adoption of music co-production in the short term. These challenges may be exacerbated by the ironic reality that, even if a musically superior co-produced music track is released, it may then prove difficult to convince sceptics that this was partially attributable to contributions from the consumer.

In the Stage Two interviews with the artist managers, S2NP, who previously acknowledged the growing importance of co-production, now suggested that few artists would be willing to release coproduced music due to 'the risk that it's not going to be up to par.' S2AK also stated in his interview that 'if the artist wants to release a track that is co-created with their fans, it's quite a risk for them and their label.' These statements provide insights into how the considerations of the artists in relation to the implications of releasing co-produce music with the fans extends beyond music quality - it may also have ramifications for their brand positioning, sales figures (and hence financial stability) and relations with their label (which, depending on the label's size and contract, may control various aspects of the artist's career). Therefore, any release of music co-production should perhaps be pre-empted with a strategy to manage these significant considerations, especially as this third consideration highlights the unique idiosyncrasies of the music industry. Grönroos and Voima (2013, p. 140) affirm that coproduction 'occurs only when two or more parties influence each other'. Our findings demonstrate that this three-party interactive system will remain in place in the music industry for the foreseeable future, as artists remain financially indebted to their label (for now). Therefore, the consumers, artists and their associated label are inextricably linked in the co-production process and any activities or initiatives must consider the needs and requirements of all parties - not just the consumer party as found in more traditional two-party co-development systems (Gosling et al. 2015).

However, the negative perceptions of the quality of music output from co-production were not entirely unanimous from the interviewees. In the Stage One interviews, three of them suggested that co-production actually represented opportunities for how artists can improve and enhance their creative output. S1TS proposed that, through co-production, artists can effectively expand their creative universe or mythology as 'it's another way to create a larger story and become a bit more personal in the whole story'. This viewpoint was reflected by S1PA who described crowdsourced music creation with the fans as having an exponentially larger impact through the formulation of music content that is both connective and inspiring. Lastly, S1RT - who had over four years' experience running a music coproduction platform, propagated the innovative and creative potential of co-production for artists by conjecturing that it could produce new creations external to recorded music with much broader implications. Ind et al. (2013, p. 5) express that, with co-production in general terms, 'organizations can now engage with consumers and explore together with them their emotions, feelings, and memories while generating deep insights.' Our findings advocate and extend this argument by suggesting that, in the music industry, the risks discussed above may be somewhat mitigated by expanding co-production 
to other associated activities related to the music. This would be carried out as a means to instil these stronger relationships with the fans, whilst developing the brand and mythology around the artist.

A summary of the key findings from the above discussion is presented in Figure 2 below, with highlighted boxes indicating the key insights that are derived from multiple interview sources, and arrows indicating the direction of influence between constructs.

[Figure 2 here]

\subsection{Impact of music co-production on music artists and labels}

A statement by S2AK - who had three years' experience of representing artists - contradicted the revenue difficulty argument by S1TH by suggesting that co-production actually represents a revenue generation opportunity for artists as well as 'an opportunity to develop the fan base to create loyal core fans.' These findings provide insights into how the effective implementation of music co-production activities may have auxiliary effects on marketing and finance for the artists. This particular combination of opportunities corroborates views expressed by Stafford (2010, p. 117), who proposes that music content co-production, and the subsequent consumer loyalty interactions through voting on co-produced remixes, can give the consumers 'a greater appreciation for the music production process, that is thought to possibly reduce levels of piracy and encourage fans to purchase their music instead of stealing it'. However, the Stage One interviewees advanced these literature suggestions of monetisation through increased consumer loyalty by also suggesting that the artists and labels can monetise coproduction activities in other ways. For instance, S1MM advised on the socially and technologically driven monetisation processes of co-production of content through YouTube channels, although S1WS cautioned that direct revenue generation depends on sufficient platform coverage - which YouTube alone does not currently provide - as well as strategically placed legal frameworks. Therefore, it may be advisable for artists and labels to develop co-production initiatives with a view to short-term indirect revenue generation, whilst opting for direct revenue generation through YouTube (or other similar channels) as their long-term strategy once platform coverage increases.

S1MP provided an alternative perspective by concentrating on more indirect monetisation techniques for artists and labels by exploiting the revenue generated by remixers or the resurgence in awareness through fan-remixes of previous music content. This viewpoint adds new dimensions to the existing literature discussion on indirect revenue generation from content co-production, in which Jarvenpaa and Lang (2011, p. 448) expressed that 'although the band does not monetise the content [...] directly, generated content gives the band information about what their core fans like, and it might help them in determining what they produce next'. These raised points by the interviewees demonstrate considerably more expansive insights by providing evidence of direct and indirect revenue generation strategies for both artists and labels. Thus, we now know that fan-remixes of artist content, despite their 
potential copyright infringement, may not only benefit artists in terms of deeper engagement from the fans, but also in terms of simultaneous direct and indirect revenue opportunities.

Aside from the themes discussed above, many of the interviewees across the three interview stages raised other dependency factors that they believed affect how co-production is perceived, adopted and successfully executed by the artists and labels. In the Stage Two interviews with the artist managers, S2NP argued that the level of opportunity for co-production depends on the strength of marketing skills exhibited by the artist. In the Stage Three follow-up interview with S1AM, he also cited artist skills as a dependency factor but these related to diligence regarding the timing of co-production content releases and the amount of co-produced music to be released. His rationale was that other consumers would not be satisfied with a long-awaited album release that featured collaborative content from 'a bunch of other people whom I didn't care about'. This viewpoint was reflected in the Stage One Interview with S1MK who admitted that the entire album of co-produced music that his band released did not generate considerable revenue. Henkel and von Hippel (2005, p. 18) describe how co-production in non-music contexts can benefit industry stakeholders if they implement 'strategies that integrate user innovation more closely (and consciously) with their own product development efforts'. Our findings concur with this statement, whilst providing additional insights into the complexities of factors influencing the success - both financial and otherwise - of co-production strategies in the music industry. Thus, it appears that, despite shifting preferences towards co-production from the consumers and technology enablers, the most critical factor is that artists exhibit and balance the right combination of attributes including not only product development alignment but also marketing proficiencies and knowing when and how much co-produced music to release.

S1RA - who had six years' experience managing a consumer-run record label - suggested that remixing would be confined to electronic music and not affect mainstream genres of pop and rock so much. This viewpoint was reflected in the Stage Three interview with S1AM in which he suggested that co-production was more commonplace in dance music genres. In Stage Two, S2JJ - who has over twenty-two years' experience of managing artists from non-popular genres -stated that there is more opportunity for co-production in general in popular music genres as opposed to jazz or classical. These statements appear to apply that the complexity of the music content, an aspect that is genre-specific, may dictate opportunities for co-production - at least in the short-term. Despite all of these suggestions, however, S1PA expressed strong views that there are no genre-specific limitations on co-production. He stated that 'it is going to innovate in every genre, and that this co-creator remix culture is really going to just disrupt everything.' He provided the example of the Eric Whitacre Choir that was a classical co-production project and proclaimed that co-production will innovate - and already is innovating - in every musical genre. This insight finds support for a statement by Knobel and Lankshear (2008, p. 24), who also challenge the viewpoints regarding remixing being limited to dance music by stating that 'some singers and bands-like Jay-Z_encourage remixing and make mixable versions of their work available online for downloading and tinkering'. Building on this construct, our findings 
expose the genre ubiquity and multifarious nature of future co-production trends as fans become increasingly savvy, despite lacking technical musical abilities, and use their peripheral skills to engage in increasingly complex co-production in a diverse range of styles and genres.

A summary of the key findings from the above discussion is presented in Figure 3 below, with highlighted boxes indicating the key insights that are derived from multiple interview sources, and arrows indicating the direction of influence between constructs.

[Figure 3 here]

\subsection{Artist approaches to music co-production}

Some of the interviewees across the three interview stages suggested that the stage of an artist's career represents a key dependency factor. In the Stage One interviews, S1AM suggested it was "probably more so with [do-it-yourself] artists.' This viewpoint was reflected by S1CS in his Stage Three followup interview in which he suggested that co-production projects 'often seem to be more from indie artists.' Although these two comments would initially appear to suggest that early-stage independent artists would be most appropriately suited for co-production of experiments with consumers, S1PS urged that it is actually 'easier for more established artists to let somebody in because they have already established their artistic footprint'. Jarvenpaa and Lang (2011, p. 448) contend that fans who engage in co-production 'must not be allowed to harm the artistic reputation of the band by digressing too far from the known sounds'. Our findings advance this statement by demonstrating that the lack of brand identity from rising artists may be holding them back from instigating co-production initiatives, despite the fact that they would most likely have more artistic freedom to do so compared with their more established counterparts. As the relinquishment of control - whether from inflexible label structures or from rising artist apprehensions - may result in new and innovative musical offerings, the potential benefits may be worth the risk.

The issue of negative artist perceptions towards co-production was cited by several interviewees throughout the three-stage interview process, with three of them suggesting the notion of creative protection as a rationale for artists not being open to incorporating another people's creative input into their work. However, there were suggestions in the interviews that these issues could be converted into an opportunity; S1MK explained in his Stage One interview that his band designed their co-production experiment so that they could maintain creative control over the finalised content. This was achieved by requesting remix content from the fans, receiving it and then deciding on 'whether or not they were of sufficient quality or the right style or whatever that we will be happy to then circulate.' It therefore appears that the best strategy for artists to maintain artistic control is not through litigation against co-production, but by embracing it through regulated, proactive initiatives. This strategy is alluded to by Jarvenpaa and Lang (2011, p. 448), who describe a co-production fan community for the 
band Nine Inch Nails where 'members cannot take music off the site and release it elsewhere. As a firmsponsored fan community, NIN exercises hierarchical control'.

The aspect of authenticity was raised by the artist manager S2NP in her Stage Two interview when she claimed that co-production activities were not a genuine inclusion of consumers into the artistic creation of music, but merely a channel through which to 'lure the fans in' and make them believe this fabrication. Moreover, S1WS expressed in his Stage Two interview that the loss of control associated with co-production creates increasingly difficult questions regarding the artist's moral rights. Therefore, this combination of ethical considerations and the level of creative control may be of vital importance for artists or labels in terms of striking a balance between their strategic goals of the coproduction campaign and their expected concessions. In the Stage Two interviews with the major label representatives, S2FB provided an alternative perspective on the discussion of ethical issues by emphasising the need for co-production of campaigns that were not only genuine and sincere for the consumers but also the artists. He explained that 'Where it falls down is if it feels like something that's just done because it's something on somebody's checklist.' S2KS, another major label senior manager, reflected this viewpoint by reiterating that co-production is not well suited to the artistic vision of every musician and that labels should not apply pressure on the artists to engage in these types of activities. He commented that 'Some artists are interested in collaborating; some artists want to deliver their vision intact to the market.' These points emphasise the context-specific nature of co-production implementation for artists and labels, in addition to how modern consumers will not appreciate coproduction initiatives unless they perceive them as an unpretentious opportunity for emersion into the creative process.

The statements made by S1TH - who had two years' experience of music co-production through working with a major record label - indicated that, even if artists overcome the perceived risks regarding low quality production and exhibit a more open-minded outlook towards creative collaborations with the consumers, there are still substantial logistical and business model challenges preventing them from taking full advantage. This viewpoint is supported by Wikström (2012, p. 16), who discusses how the artist Imogen Heap 'invites her fans to contribute with sounds, words, images, and videos that she uses as building blocks in the making of the songs. It is difficult to determine whether [the] business model for the new album project really is viable.' In his Stage One interview, S1TH also cited other logistical or business model limitations that were impeding development of co-production of practices for artists. He suggested substantial difficulties relating to revenue generation and business model sustainability surrounding co-production. These views were reflected by S1AM in his Stage Three interview in which he casted doubt over the potential of co-production to generate revenue if the co-produced tracks were integrated into a studio album of original music by the artist. He concluded by describing co-production as 'a nice to have' but that he doesn't think that 'an artist absolutely needs to do that sort of thing to survive'. It therefore appears that co-production may have to be amalgamated 
with other more innocuous income-generating practices that would counter-balance any revenue instability associated with the co-production elements.

A summary of the key findings from the above discussion is presented in Figure 4 below, with highlighted boxes indicating the key insights that are derived from multiple interview sources, and arrows indicating the direction of influence between constructs.

[Figure 4 here]

\subsection{Major label approaches to music co-production}

Licensing limitations from the record label were a particular logistical issue that S1TH raised in his Stage One interview. He stated that the major labels may struggle to allocate business space for co-production due to their licenses and as a result they cannot permit the activity. In the Stage Two interviews with the major record label senior executives, two of them also raised the issue of licensing limitations. S2JH advised that 'You have to really drill down to some case by case approval [...] because otherwise you haven't got a consistency across the deals.' S2FB went as far as to describe co-production for them as a 'nightmare to do from a licensing perspective'. These viewpoints expound the realities and practicalities of co-production from a legal standpoint, whilst they also substantiate a statement by Harhoff et al. (2003, p. 4) on co-production in general, in which they claim that '[t]he owners of intellectual property may have little incentive to license it because the mechanism is too complex and involves high transaction costs'. Building on this premise from a music industry context, we now know that the perceptions of labels as reluctant to embrace co-production innovations within the industry may be misplaced, as they are circumvented by licensing regulations and complexities. Despite this, there have been infrequent documented cases of co-production initiatives sanctioned by the labels. Hence, in future it may be advisable for the labels to take a more transparent and creative approach to coproduction, so that consumers are more aware of label licensing limitations as well as their steps to bypass them by facilitating other peripheral co-production activities.

In his interview, S2FB discussed the prospect of a proactive co-production experiment in which he expressed uncertainty about the true value it would realise for them. He stated that 'I don't know that it drives any commercial value. Certainly it carries a cost to us as a business.' This viewpoint arguably demonstrates an example of business model inflexibility from the major labels with regard to value chain adaptations. In the non-music literature, Berman (2012, p. 20) suggests that 'companies focused on fully reshaping the operating model optimize all elements of the value chain around points of customer engagement'. Our findings ironically demonstrate that it is actually value chain optimisation that is preventing the major labels from relinquishing their business model inflexibilities, as confirmed in a statement by S2JW that "they can see the value and the effort that is needed to make [co-production] work" in conjunction with their superior marketing expertise and younger employee demographics. Accordingly, we now know that the cost implications of co-production, although negligible compared 
with their income generation from distribution and ticketing channels, must nevertheless be considered in terms of corresponding marketing and commercial valuation before any operational restructuring can occur.

Two of the other major label interviewees discussed the aspect of marketing value in particular through co-production campaigns. For instance, S2KS suggested that 'I don't think that's going to be a real growing and important part of the industry. But I think it is quite cool little marketing thing to get involved in for the right sort of music.' This point returns the discussion to the aspect of creative limitations with proactive co-production initiatives. In the non-music literature, Gebauer et al. (2013, p. 1525) comment that a positive co-production experience "may then contribute to spreading the word and willingness to pay.' Our findings support and advance this statement as they indicate that the major labels can benefit more from adopting a combination of these two approaches to co-production in order to derive both economic and marketing value. In terms of the exact economic value that co-production can have for artists, labels or other industry firms, many of the interviewees admitted to having a lack of knowledge in this regard. It therefore appears that further research of a quantitative nature may be required in order to ascertain the exact financial impact for various industry actors. This aspect echoes a lack of economic value/cost implications of co-production in other industry sectors; Auh et al. (2007, p. 368) focussed their study on the financial services sector and concluded that 'It would be worthwhile to explore firms' transaction costs associated with integrating customers more fully into the production process'.

A summary of the key findings from the above discussion is presented in Figure 5 below, with highlighted boxes indicating the key insights that are derived from multiple interview sources, and arrows indicating the direction of influence between constructs.

[Figure 5 here]

\section{Conclusions}

This research paper set out to explore the phenomenon of content co-production in the music industry from the perspective of how the consumer role is changing, how co-production affects the quality of music content, how key stakeholders are being affected and how they are now approaching (or should approach) co-production. Based on the analysis of the interview data and the proposal of theoretical frameworks in Figures 1-5, conclusions are now drawn.

In relation to the changing role of the consumer in music production, and how this interrelates with the study's aim of exploring the effects of co-production on music artists and labels, Figure 1 demonstrates the complexity of this topic whilst highlighting the key findings raised by multiple interviewees. One key finding relates to how consumers are now transitioning into a consumer-artist role. In this regard, we advance existing theory by Grönroos and Voima (2013) by demonstrating how this is leading to the boundaries of the industry's value sphere extending upwards through hierarchical 
channels, thus creating disruptive innovations for artists and labels as consumers inject the industry with new creative content and ideas. We also build upon existing co-production literature by theorising that it is the combination of lower entry barriers and higher distribution quality resulting from technological advances that represent a key enabler for consumer-artists. We propose that this democratisation of previously hierarchical roles within the industry facilitates a paradigm shift in how stakeholders manage their relationships with artists and associated content. The implications of the alternative transition of the consumer role into that of a non-musical content co-producer are realised through the resultant consumer-created visual media products and campaigns. Here we underscore adaptability as a key constituent of industry stakeholder strategies to drive innovation growth in music co-production. We also move beyond the more descriptive music industry literature by proposing that, through a controlled approach by the artists of facilitating consumer non-music talent input in earlystage content production, then subsequently insourcing professional input, high production quality (and thus sales) can be maintained whilst the consumer contribution remains intact. With live sector fancreated audio/video recordings, we advise that a lack of understanding is perpetuating a substantial resistance in the short-term from artists and their representatives as they cannot control for the social sharing of low quality recordings. However, we conclude that the influence in the longer term is potentially more promising as the overcoming of these technical issues through regulation will result in associated business model adaptations. This is particularly salient for the labels, as they embrace these types of recording co-production whilst generating indirect revenue through social media advert monetisation.

In relation to the quality of content from music co-production, and how this interrelates with the impact on artists and labels, Figure 2 highlights the key themes from multiple interview sources that have been analysed in this study. Our findings oppose the theoretical view that the new consumerproducer role is invariably considered as a resource in the firm's production process (Grönroos and Voima 2013). In fact, in the music industry, production hindrances associated with co-production are multi-faceted and integrated across the stakeholder paradigm. For example, our findings demonstrate that the perceived as well as actual quality lowering of content as a result of co-production are not only legitimate concerns for the stakeholders but also have complex implications for their management strategies. The perceived inferiority prejudice from other consumers alone, regardless of the actual quality levels, will contribute to negative brand associations of the artist's music. However, our findings reveal that this is compounded with independent inferiority perceptions by the artists, as they heed label reservations over potentially detrimental brand positioning and sales implications. These two streams of concern are feeding into the slow adoption of co-production releases by artists in the short term, as it is undoubtedly considered a commercial risk for both the artists and the labels. This, naturally, is exacerbated by the actual dilution of content quality, which we conclude is the key challenge to be overcome. This is because it is habitually driven by the lack of talent from the consumers but, more importantly, this confirms the consumer inferiority perceptions, thus signifying a vicious circle. As 
indicated in our model, however, this is not necessarily a perpetual loop as the commercial risks associated with these two key issues can be mitigated in a number of ways. For instance, as multiple interviewees argued, co-production can also represent a sizeable opportunity for artists to enhance the quality of their creative output. This can lead to a creative mythology around their music that is more expansive and personal to the consumers (particularly those involved in the co-production). Building on more generalised insights into the positive ramifications of co-production (Ind et al.2013), we argue that the implications for the music industry include the augmentation of pre-established positive artist attributes by producing fresh new music content and instilling artist-fan relations with a deeper sense of engagement. However, they also serve to counteract some of the negative brand associations driven by the co-production sceptics. Ultimately, through the analysis of our findings, we build on the theory of multiple-party pre-requisite for co-production proposed by Grönroos and Voima (2013) by advising that artists and labels work collaboratively together, in triangulation with these innovative consumers, to pre-empt a strategy to manage risk factors prior to the release of music co-production. Ideally, this more long-term strategy would involve the appropriate allocation of credit to the consumers in such a way that their contribution is accepted and appreciated by the larger public, whilst complementing the aesthetic values of the artist.

In relation to the direct and indirect impact of co-production on music artists and labels, Figure 3 depicts the relationships between our key insights, as derived from the analysis of multiple interview sources and extant literature. One key insight is that, over time, as consumers become progressively tech savvy and peripherally skilled, the proliferation of co-production will transcend genres and unlock direct revenue generation and fan base relationship marketing. However, our results also advance current understandings by revealing that the key dependency factor at this stage in unlocking even more impactful opportunities is the artists' aptitude in exhibiting and balancing the alignment of their content, marketing proficiencies and timing skills. If these conditions are met, then we propose that both the artists and labels would benefit from more positive fan reactions to music co-production (and therefore enhanced loyalty) as well as indirect revenue prospects. Building on previous music industry research that discusses the indirect monetisation implications of co-production in general terms (Jarvenpaa and Lang 2011), our findings specifically suggest that this indirect revenue would be socially-driven and propagated by fan-remixes, which would raise awareness of the original music content. However, we also argue that it would then translate into more technologically-driven monetisation as the content is shared through YouTube or similar channels. For the labels, in future they may also derive more direct profits through this process, although this would depend on increases in platform coverage and strategically-implemented legal frameworks. Ultimately, we conclude that artists and labels should advance from short-term indirect financial benefits to more long-term direct benefits in future as these issues are alleviated.

In relation to current and future artist approaches to music co-production, Figure 4 summarises the four key insights that were expressed by multiple interviewees. The first corresponds with creative 
control, in which we have observed how artists are currently inhibited from taking a more open approach on account of creative protection of their content. This issue is intensified by the questions surrounding their moral rights in the event of loss of creative control. As a result of these insights, our recommendation for future approaches is to retain artistic control whilst espousing co-production via regulated, proactive initiatives. We conclude that this combinative approach of ethical consideration and control regulation may prove instrumental for balancing the strategic goals of co-production with anticipated concessions. We found that their career stage influences artist appositeness and inclination to engage with co-production. Building on the theoretical work of Jarvenpaa and Lang (2011), our findings demonstrate that rising artists are resistant to fully embracing co-production due to their underdeveloped brand identity - despite their otherwise greater artistic freedoms compared with their more established counterparts. As a result of these findings, we recommend moving towards controlrelinquishing approaches by authorising unofficial fan-remixes. We propose that this recommendation could be implemented under the provisions of the previous one, in which artists could still maintain IP control through regulation. Regarding authenticity, multiple interviewees expressed the view that insincere campaigns from artists could mislead consumers and result in a betrayal of trust. Subsequently, it is recommended that, in future, artists should safeguard the authenticity of coproduction campaigns for them and the consumers, as a precursor to unpretentious creative collaboration between the two parties. It was expressed across several interviews that the artist's approach to co-production strategies is often complicated by impediments with generating revenue and sustaining the business model after integrating co-production. Consequently, we recommend that artists merge co-production with alternative revenue generation streams in order to counter-balance stability issues.

In relation to how the major labels are currently approaching music co-production and future recommendations, Figure 5 visualises the key insights from the multiple interview analysis. The first of these relates to licensing, in which we established that seemingly negative label approaches to music co-production are no longer attributable to autocracy and innovation resistance but rather the encroachment of licensing complexities. Advancing the theoretical work of Harhoff et al. (2003) regarding cost and mechanism convolutions for IP owners more generally, we argue that this has resulted in inabilities for music industry labels to allocate business space for co-production. Furthermore, when it is permissible, legal representatives must be involved in the process on a case-bycase authorisation basis in order to maintain consistency across the deals. Despite these innovation hindrances, the major labels have made some strategic choices to allow consumers to post their usergenerated artist-related content on YouTube, in which the labels could then generate revenue via YouTube's content ID system. Accordingly, we recommend that labels implement a more open and creative approach to their co-production limitations. This tactic may benefit them in terms of dispelling negative perceptions, as the consumers will be better informed of the true limiting factors, thus germinating stronger relations with paying consumers. It transpired in this study that a proactive 
approach to co-production would prove economically inefficient for the labels as the inherent costs would counterbalance the commercial value derived from the initiative. This discounts the suggestion by Berman (2012) that the optimisation of value chain points of customer engagement is the solution to reshaping the operating model. Rather, we have revealed that it is this optimisation that is circumventing the label attempts to relinquish their business model inflexibilities. Multiple interviewees have argued that, despite any perceived genre restrictions of co-production, the labels have demonstrated, in isolated cases, a clear inclination towards co-production engagement due to associated marketing value attributes. Our recommendation is that labels should reassess their value chain optimisation and cost considerations against both commercial and marketing value. This reassessment may assist in restructuring their operations for co-production, whilst driving both economic and marketing value.

\subsection{Implications for industry, policy and future research}

Due to the inductive nature of this research study, our findings offer theoretical generalisation and thus have broader implications for co-production. For instance, there has been a paucity of understanding of the firm implications of consumers experimenting with products that are created by the firm (Berthon et al. 2007). We contribute to this understanding by demonstrating that this can lead to disruptive innovations for the firm, as the new product/idea may invigorate the market (thus raising awareness of the original product) but may also lead to precarious brand perceptions as the product evolves beyond the firm's IP control. We have also shown how the firm implications of co-production will undoubtedly change over time, as the progressive up-skilling of consumers in both technological and content-related proficiencies will lead to both opportunities (financial and marketing) and challenges (brand identity and IP legality) for more aspects of the firm's business model. The management literature has also called for more research into how firms can engage with - or even actively employ - consumers for coproduction purposes (Rowley et al. 2007; Jeppesen and Frederiksen 2006). We address this gap by arguing that an implementation strategy should be in place to balance the strategic goals of the coproduction with any anticipated concessions. This should involve integrating fail-safes to retain IP control of the content through regulation, whilst affording the consumers opportunities for meaningful creative contributions. Due to the financial risk factors to business model stability associated with incorporating consumers in this way, less established firms should implement the co-production activities in coalition with more certified revenue generation streams. Furthermore, it has been suggested that there is still insufficient knowledge on conflict management for co-production projects (Gebauer et al. 2013). We contribute to this knowledge base by advising that co-production has the ability to destabilise the hierarchical structure of industry value spheres as the consumer role extends upwards. This democratisation may enable more open and transparent communication and relationships to develop between industry stakeholders. Through the instigation of a two-stage co-production process in which consumers are involved in the early stages and professionals at the later stages, this 
circumvents any potential conflict of input from either party whilst maintaining sufficiently high production standards for market distribution.

The results and conclusions from this study also have policy implications for the creative and music industries at the local, regional, national or even international level. For instance, a recent IFPI music industry report (2017) stated that policy discourse around the world is still debating the best strategies for protecting artist rights in the digital age. The present study sheds some light on this subject by addressing the complexities associated with the moral rights of artists and the IP challenges of the labels in relation to the rising phenomenon of co-production. Thus, the proposed recommendations for future approaches to co-production by the artists and labels, which take into account these inherent moral and legal conundrums, would also be of interest to policy-makers. This is in terms of developing new strategies for protecting and managing the rights of music artists in future, as the approaches of artists and labels towards music co-production evolve.

Due to the exploratory nature of this study, in addition to the lack of previous research within this specific industry context, the findings from this research paper could be used as a starting point from which to develop more nuanced theories in relation to co-production. The five theoretical models presented in this study (see Figures 1-5) should be used to structure further co-production research investigation into the music industry. Our study was limited by the parameters of our resources - it was not possible to explore co-production within every conceivable music industry stakeholder group, hence the lack of empirical generalisability of our findings. Future research could focus on other related stakeholders, such as independent labels and major artists and examine how the implications of coproduction compare with their counterparts. It was also decided, due to the industry perspective of the study, to conduct interviews only with industry representatives. Future consumer research could therefore involve a large data collection (either qualitative or quantitative) from the consumers in order to compare and build upon this study's findings. As this study focused on one of the thirteen creative industries, as defined by the UK's Department of Culture, Media and Sport (DCMS 1998), the findings should also be advanced by further comparative research into other related creative industries. For instance, the insights in relation to the implications of consumer contributions to the development of core and peripheral products could be explored within the fashion, craft or TV/movie industries. Finally, more research into the revenue-generation potential of music co-production has been concluded as necessary due to the unanimous lack of knowledge from across the stakeholder groups and interview stages. It therefore appears that further research of a quantitative nature is required in order to ascertain the exact financial impact of co-production on various industry stakeholders.

\section{References}

Adebanjo, Dotun, Matthew Tickle, Tritos Laosirihongthong, and Robin Mann. 2015."A Study of the use of Business Improvement Initiatives: The Association with Company Size and Level of National Development." Production Planning \& Control 26, no. 7: 507-524.

Anderson, Chris. 2009. The Longer Long Tail: How Endless Choice is Creating Unlimited Demand. London: Random House Business Books. 
Anixter, Julie. 2015"Interview with Craig Swann, Music Innovator, on the Launch of LoopLabs." http://innovationexcellence.com/blog/2015/11/24/interview-with-craig-swann-music-innovatoron-the-launch-of-looplabs/. Accessed 25/03/2016.

Auh, Seigyoung, Simon J. Bell, Colin S. McLeod, and Eric Shih. 2007."Co-Production and Customer Loyalty in Financial Services." Journal of Retailing 83, no. 3: 359-370.

Berman, Saul J. 2012."Digital Transformation: Opportunities to Create New Business Models." Strategy \& Leadership 40, no. 2: 16-24.

Berthon, Pierre, Leyland F. Pitt, Ian McCarthy, and Steven M. Kates. 2007."When Customers Get Clever: Managerial Approaches to Dealing with Creative Consumers." Business Horizons 50, no. 1: 39-47.

Bourreau, Marc, Michel Gensollen, and François Moreau. 2012."The Impact of a Radical Innovation on Business Models: Incremental Adjustments Or Big Bang?" Industry \& Innovation 19, no. 507: 415-435.

Brown, Steven Caldwell. 2014."'With a Little Help from My Friends': Peer Production and the Changing Face of the Live Album." International Journal of Music Business Research 3, no. 1: 52-66.

Burmann, Christoph. 2010."A Call for 'user-Generated Branding'." Journal of Brand Management 18, no. 1: 1-4.

Cammaerts, Bart, Robin Mansell, and Bingchun Meng. 2013. Copyright \& Creation: A Case for Promoting Inclusive Online Sharing: LSE Media Policy, 1-18.

Chaney, Damien. 2012."The Music Industry in the Digital Age: Consumer Participation in Value Creation." International Journal of Arts Management 15, no. 1: 42-52.

Choi, Hwanho and Bernard Burnes. 2013."The Internet and Value Co-Creation: The Case of the Popular Music Industry." Prometheus 31, no. 1: 35-53.

Cova, Bernard and Daniele Dalli. 2003. "From Communal Resistance to Tribal Value Creation."28th November 2008, Paris, France, 1-22.

DCMS. 1998. DCMS Mapping Document 1998. Department for Culture, Media and Sport, 1-10.

DeCuir-Gunby, Jessica T., Patricia L. Marshall, and Allison W. McCulloch. 2011."Developing and using a Codebook for the Analysis of Interview Data: An Example from a Professional Development Research Project." Field Methods 23, no. 2: 136-155.

Di Gangi, Paul M. and Molly Wasko. 2009."Steal My Idea! Organizational Adoption of User Innovations from a User Innovation Community: A Case Study of Dell IdeaStorm." Decision Support Systems 48, no. 112: 303-312.

Echeverri, Per and Per Skålén. 2011."Co-Creation and Co-Destruction: A Practice-Theory Based Study of Interactive Value Formation." Marketing Theory 11, no. 3: 351-373.

Edhlund, Bengt. 2011. Nvivo 9 Essentials www.Lulu.com. Accessed 06/07/2017.

Elo, Satu and Helvi Kyngäs. 2008."The Qualitative Content Analysis Process." Journal of Advanced Nursing 62, no. 1: 107-115.

Gamble, Jordan Robert, Michael Brennan, and Rodney McAdam. 2017."A Rewarding Experience? Exploring how Crowdfunding is Affecting Music Industry Business Models." Journal of Business Research 70C: 25-36.

Gamble, Jordan Robert and Audrey Gilmore. 2013."A New Era of Consumer Marketing? An Application of Co-Creational Marketing in the Music Industry." European Journal of Marketing 47, no. 11/12: 1859-1888.

Gebauer, Johannes, Johann Füller, and Roland Pezzei. 2013."The Dark and the Bright Side of CoCreation: Triggers of Member Behavior in Online Innovation Communities." Journal of Business Research 66, no. 9: 1516-1527.

Gosling, Jonathan, Denis R. Towill, Mohamed M. Naim, and Andrew RJ Dainty. 2015."Principles for the Design and Operation of Engineer-to-Order Supply Chains in the Construction Sector." Production Planning \& Control 26, no. 3: 203-218.

Grönroos, Christian and Päivi Voima. 2013."Critical Service Logic: Making Sense of Value Creation and Co-Creation." Journal of the Academy of Marketing Science 41, no. 2: 133-150.

Guba, Egon G. 1981."Criteria for Assessing the Trustworthiness of Naturalistic Inquiries." Educational Technology Research and Development 29, no. 2: 75-91. 
Gyrd-Jones, Richard I. and Niels Kornum. 2013."Managing the Co-Created Brand: Value and Cultural Complementarity in Online and Offline Multi-stakeholder Ecosystems." Journal of Business Research 66, no. 9: 1484-1493.

Harhoff, Dietmar, Joachim Henkel, and Eric von Hippel. 2003."Profiting from Voluntary Information Spillovers: How Users Benefit by Freely Revealing their Innovations." Research Policy 32, no. 10: 1753-1769.

Henkel, Joachim and Eric von Hippel. 2005."Welfare Implications of User Innovation." Journal of Technology Transfer 30, no. 1-2: 73-87.

Hsieh, Hsiu-Fang and Sarah E. Shannon. 2005."Three Approaches to Qualitative Content Analysis." Qualitative Health Research 15, no. 9: 1277-1288.

IFPI. 2017. Global Music Report 2017: Annual State of the Industry, 1-44.

Ind, Nicholas, Oriol Iglesias, and Majken Schultz. 2013."Building Brands Together: Emergence and Outcomes of Co-Creation." California Management Review 55, no. 3: 5-26.

Izvercian, Monica and Sabina Alina Seran. 2013. "The Web 2.0 and the Globalization Impact on New Consumer Emergence and Classification." Tianjin, China, Atlantis Press, 22nd August 2013.

Jarvenpaa, Sirkka L. and Karl R. Lang. 2011."Boundary Management in Online Communities: Case Studies of the Nine Inch Nails and ccMixter Music Remix Sites." Long Range Planning 44, no. 5: 440-457.

Jeppesen, Lars Bo and Lars Frederiksen. 2006."Why do Users Contribute to Firm-Hosted User Communities? the Case of Computer-Controlled Music Instruments." Organization Science 17, no. 1: 45-63.

Johnson, Phil, Anna Buehring, Catherine Cassell, and Gillian Symon. 2007."Defining Qualitative Management Research: An Empirical Investigation." Qualitative Research in Organizations and Management: An International Journal 2, no. 1: 23-42.

Jones, R. 2012."Chapel Club Release Song Stems for Remix, Fans can Keep Profits and Rights." Music Week. http://www.musicweek.com/news/read/chapel-club-release-song-stems-for-remixfans-can-keep-profits-andrights/051933?utm_source $=$ feedburner\&utm_medium $=$ feed\&utm_campaign $=$ Feed $\% 3 \mathrm{~A}+$ musicw eek\%2Fstream+\%28Music+Week\%3A+Stream\%29. Accessed 02/03/2017

Knobel, Michele and Colin Lankshear. 2008."Remix: The Art and Craft of Endless Hybridization." Journal of Adolescent \& Adult Literacy 52, no. 1: 22-33.

Knox, Karl. 2003."A Researcher's Dilemma-Philosophical and Methodological Pluralism." Electronic Journal of Business Research Methods 2, no. 2: 145-154.

Leech, Nancy L. and Anthony J. Onwuegbuzie. 2007."An Array of Qualitative Data Analysis Tools: A Call for Data Analysis Triangulation." School Psychology Quarterly 22, no. 4: 557-584.

Lengnick-Hall, Cynthia A. 1996."Customer Contributions to Quality: A Different View of the Customer-Oriented Firm." Academy of Management Review 21, no. 3: 791-824.

Lettl, Christopher, Cornelius Herstatt, and Hans Georg Gemuenden. 2006."Users' Contributions to Radical Innovation: Evidence from Four Cases in the Field of Medical Equipment Technology." $R \& D$ Management 36, no. 306: 251-272.

Lettl, Christopher, Christoph Hienerth, and Hans G. Gemuenden. 2008."Exploring how Lead Users Develop Radical Innovation: Opportunity Recognition and Exploitation in the Field of Medical Equipment Technology." IEEE Transactions on Engineering Management 55, no. 205: 219-233.

Löfberg, Nina, Lars Witell, and Anders Gustafsson. 2015."Service Manoeuvres to Overcome Challenges of Servitisation in a Value Network." Production Planning \& Control 26, no. 14-15: 1188-1197.

Lusch, Robert F. and Stephen L. Vargo. 2006."Service-Dominant Logic: Reactions, Reflections and Refinements." Marketing Theory 6, no. 3: 281-288.

Milena, Zaharia Rodica, Grundey Dainora, and Stancu Alin. 2008."Qualitative Research Methods: A Comparison between Focus-Group and in-Depth Interview." The Journal of the Faculty of Economics 4, no. 1: 1279-1283.

Mulligan, Mark. 2011. Agile Music: Music Formats and Artist Creativity in the Age of Media Mass Customization, 1-12.

Mulligan, Mark. 2014. The Death of the Long Tail: The Superstar Music Economy: Midia, 1-20.

Nielsen. 2017. Nielsen Music Year-End Report U.S. 2016, 1-27. 
O’Neill, Maureen. 2013. The NVivo Toolkit: How to Apply NVivo in Your PhD for Research and Publishing Success, 1-52.

Oliveira, Pedro and Eric von Hippel. 2011."Users as Service Innovators: The Case of Banking Services." Research Policy 40, no. 67: 806-818.

Plé, Loic, Xavier Lecocq, and Jacques Angot. 2010."Customer-Integrated Business Models: A Theoretical Framework." M@n@gement 13, no. 4: 226-265.

Polit, Denise and Cheryl Beck. 2004."Assessing Data Quality." In Nursing Research: Principles and Methods, edited by Polit, Denise and Cheryl Beck. 7th Edition ed., 413-447. Philadelphia, USA: Lippincott Williams \& Wilkins.

Power, Dominic and Daniel Hallencreutz. 2007."Competitiveness, Local Production Systems and Global Commodity Chains in the Music Industry: Entering the US Market." Regional Studies 41, no. 305: 377-389.

Prügl, Reinhard and Martin Schreier. 2006."Learning from Leading-Edge Customers at "the Sims": Opening Up the Innovation Process using Toolkits." $R \& D$ Management 36, no. 3: 237-250.

Ramírez, Rafael. 2005."The Aesthetics of Cooperation." European Management Review 2, no. 1: 2835.

Romero, David and Arturo Molina. 2011."Collaborative Networked Organisations and Customer Communities: Value Co-Creation and Co-Innovation in the Networking Era." Production Planning \& Control 22, no. 5-6: 447-472.

Rowley, Jennifer, Beata Kupiec-Teahan, and Edward Leeming. 2007."Customer Community and CoCreation: A Case Study." Marketing Intelligence \& Planning 25, no. 2: 136-146.

Ryan, Gery W. and H. Russell Bernard. 2003."Techniques to Identify Themes." Field Methods 15, no. 1: 85-109.

Shao, Guosong. 2009."Understanding the Appeal of User-Generated Media: A Uses and Gratification Perspective." Internet Research 19, no. 1: 7-25.

Soriano, Javier, David Lizcano, Juan J. Hierro, Marcos Reyes, Christoph Schroth, Janner Till. 2008. "Enhancing user-service interaction through a global user-centric approach to SOA." Fourth International Conference on Networking and Services. Gosier: Guadeloupe.

194-208, March 16-21.Stafford, Sadie. 2010."Music in the Digital Age: The Emergence of Digital Music and its Repercussions on the Music Industry." The Elon Journal of Undergraduate Research in Communications 1, no. 2: 112-120.

Stensaeth, Karette. 2013."'Musical Co-Creation"? Exploring Health-Promoting Potentials on the use of Musical and Interactive Tangibles for Families with Children with Disabilities." International Journal of Qualitative Studies on Health and Well-Being 8, no. 2: 1-12.

Thomas, Bernard. 2012."Coca-Cola Invites Fans to Help Jason Derulo Create Song for American Idol." Examiner. http://www.examiner.com/article/coca-cola-invites-fans-to-help-jason-derulocreate-song-for-american-idol. Accessed 06/01/2017

Vargo, Stephen L. and Robert F. Lusch. 2008."Service-Dominant Logic: Continuing the Evolution." Journal of the Academy of Marketing Science 36, no. 1: 1-10.

Warr, Richard and Mark MH Goode. 2011."Is the Music Industry Stuck between Rock and a Hard Place? the Role of the Internet and Three Possible Scenarios." Journal of Retailing and Consumer Services 18, no. 2: 126-131.

Wikström, Patrik. 2012."A Typology of Music Distribution Models." International Journal of Music Business Research 1, no. 1: 7-20.

Zhang, Yan and Barbara M. Wildemuth. 2009."Qualitative Analysis of Content." In Applications of Social Science Research Methods to Questions in Library and Information Science, edited by Wildemuth, Barbara M., 308-319. Englewood, CO: Libraries Unlimited. 
Table 1. Results of four-phase analysis of interview data

\begin{tabular}{|c|c|c|}
\hline Category & Theme & Sub-theme \\
\hline \multirow{7}{*}{$\begin{array}{l}\text { The } \\
\text { changing } \\
\text { role of the } \\
\text { consumer in } \\
\text { music } \\
\text { production }\end{array}$} & \multirow{3}{*}{$\begin{array}{l}\text { Consumers becoming } \\
\text { artists }\end{array}$} & Disruptive positive effect on industry structure \\
\hline & & Upward shift of value sphere due to new perspectives \\
\hline & & Lower entry barriers and higher distribution quality \\
\hline & \multirow{2}{*}{$\begin{array}{l}\text { Consumers becoming } \\
\text { non-musical content co- } \\
\text { producers }\end{array}$} & Early-phase production co-design input \\
\hline & & Opportunities from visual media adaptability \\
\hline & \multirow{2}{*}{$\begin{array}{l}\text { Fan-created live event } \\
\text { recordings }\end{array}$} & Involuntary business model adaptation from labels \\
\hline & & Short-term resistance \\
\hline \multirow{8}{*}{$\begin{array}{l}\text { Quality of } \\
\text { content from } \\
\text { music co- } \\
\text { production }\end{array}$} & \multirow{3}{*}{$\begin{array}{l}\text { Perceptions vs actual } \\
\text { quality }\end{array}$} & Creative talent barriers \\
\hline & & Negative brand associations \\
\hline & & Slow uptake in short term \\
\hline & \multirow[t]{3}{*}{ Artist willingness } & Additional dependency factors \\
\hline & & Need for pre-emptive strategy \\
\hline & & Three-party interactive system \\
\hline & \multirow{2}{*}{$\begin{array}{l}\text { Opportunities to } \\
\text { enhance creative output }\end{array}$} & Expansive and connective new content \\
\hline & & Risk mitigation through associated activities \\
\hline \multirow{8}{*}{$\begin{array}{l}\text { Impact of } \\
\text { music co- } \\
\text { production } \\
\text { on music } \\
\text { artists and } \\
\text { labels }\end{array}$} & \multirow[t]{3}{*}{ Revenue generation } & Auxiliary marketing/finance effects \\
\hline & & Short-term indirect revenue from fan re-mixes \\
\hline & & Long-term direct social media strategies \\
\hline & \multirow{2}{*}{ Dependency factors } & Artist marketing skills \\
\hline & & Product alignment and timing \\
\hline & \multirow[t]{3}{*}{ Genre limitations } & Current Tech-focused genres \\
\hline & & Cross-genre opportunities \\
\hline & & Future genre ubiquity due to trends and fan skillsets \\
\hline \multirow{10}{*}{$\begin{array}{l}\text { Artist } \\
\text { approaches } \\
\text { to music co- } \\
\text { production }\end{array}$} & \multirow[t]{3}{*}{ Artist career stage } & Suitability for independent artists \\
\hline & & Lack of brand identity \\
\hline & & Control relinquishment \\
\hline & \multirow{2}{*}{ Artist perceptions } & Creative protection \\
\hline & & Regulated initiatives \\
\hline & \multirow[t]{3}{*}{ Authenticity } & Moral rights \\
\hline & & Goal/concession balance \\
\hline & & Sincere creative emersion \\
\hline & \multirow{2}{*}{$\begin{array}{l}\text { Business model } \\
\text { challenges }\end{array}$} & Sustainability issues \\
\hline & & Revenue uncertainty \\
\hline \multirow{7}{*}{$\begin{array}{l}\text { Major label } \\
\text { approaches } \\
\text { to music co- } \\
\text { production }\end{array}$} & \multirow[t]{3}{*}{ Licensing limitations } & Legal complexities \\
\hline & & Perceptions of record labels \\
\hline & & Future transparency approach \\
\hline & \multirow[t]{2}{*}{ Business practicalities } & Business model inflexibilities \\
\hline & & Cost implications \\
\hline & \multirow{2}{*}{$\begin{array}{l}\text { Marketing/economic } \\
\text { value }\end{array}$} & Creative limitations \\
\hline & & Combination approach \\
\hline
\end{tabular}




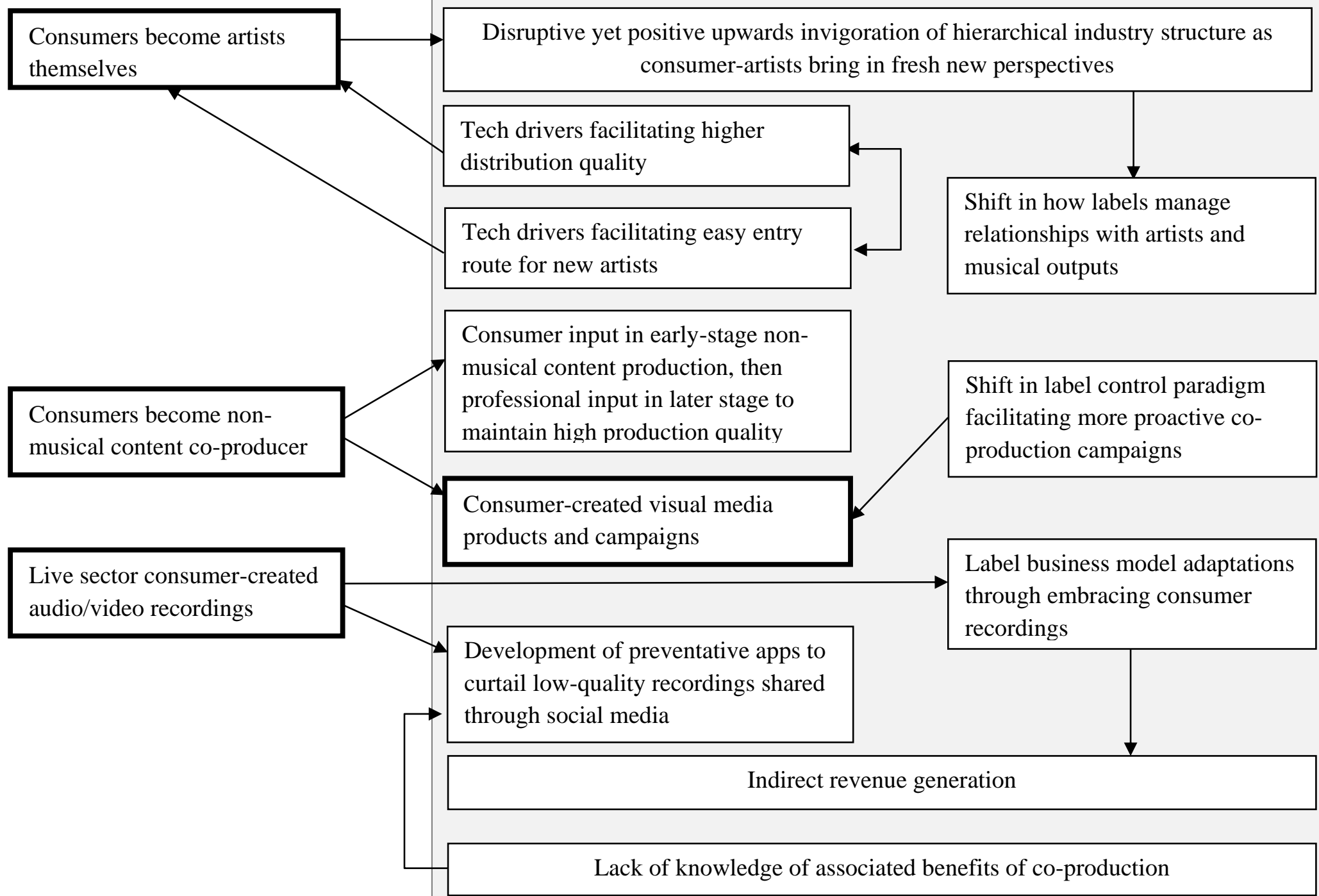

Figure 1. The transformative role of the consumer in music co-production 


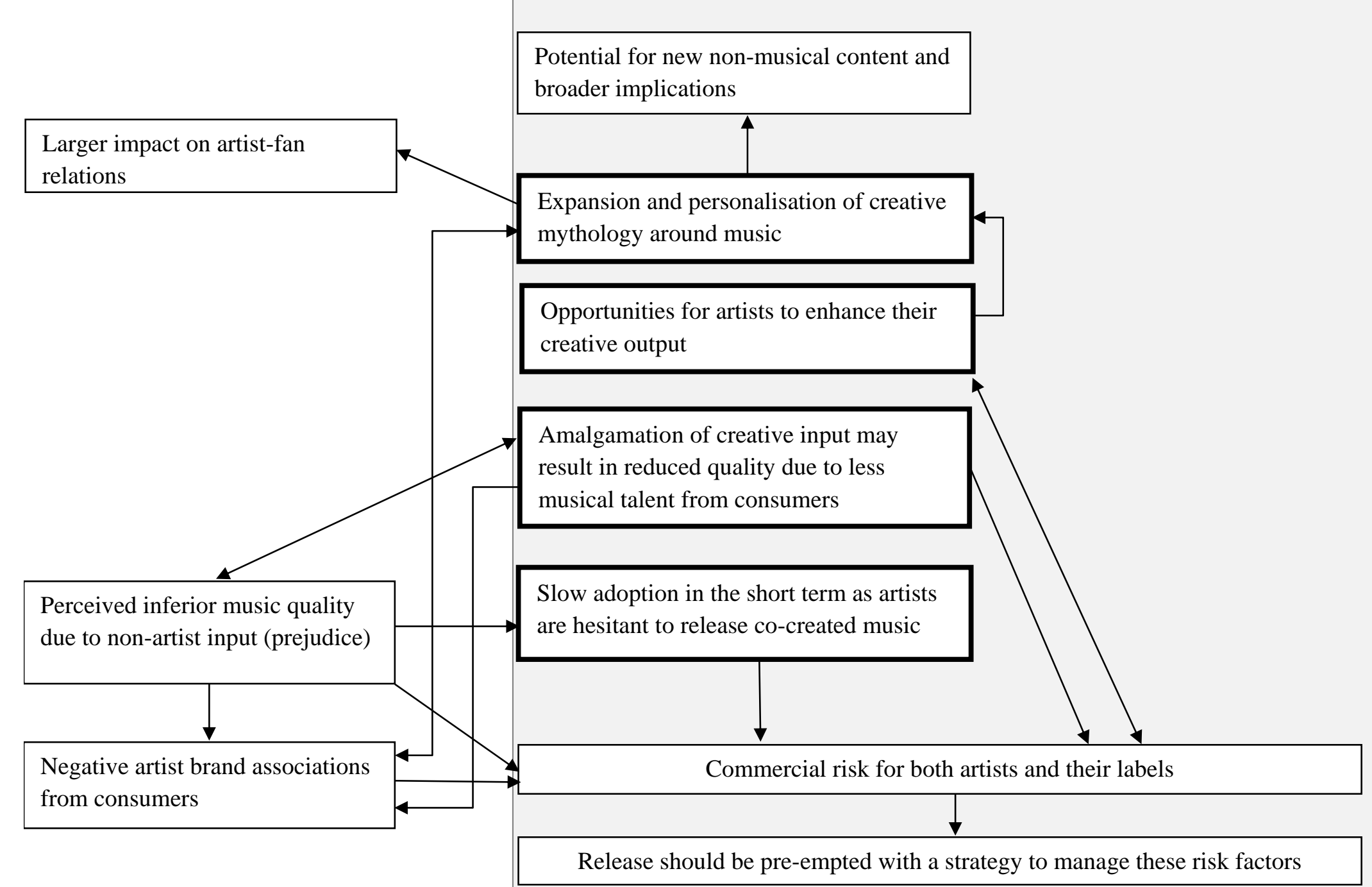

Figure 2. The impact of music co-production quality on industry stakeholders 




Figure 3. Impact of music co-production on industry stakeholders 
Creative protection preventing artists from becoming open to external contributions

Creative control

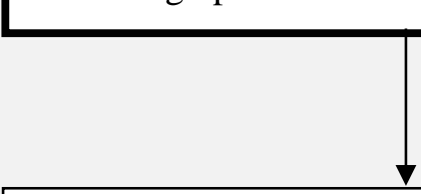

The loss of control creates difficult questions regarding the artist's moral rights
Career stage affects appropriateness and willingness to engage in co-production
Lack of brand identity from rising artists preventing them from fully embracing
Authenticity

\section{Career stage}

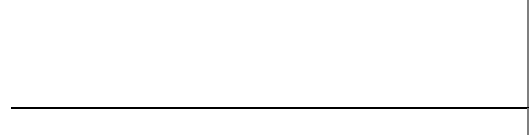

\begin{tabular}{l} 
Authenticity \\
\hline Business model logistics
\end{tabular}

Authenticity issues as insincere campaigns

from artists can mislead fans and lead to

hetraval of trust
Approach is affected by difficulties with revenue generation and business model sustainability
Artists should maintain artistic control by embracing co-

production through regulated, proactive initiatives

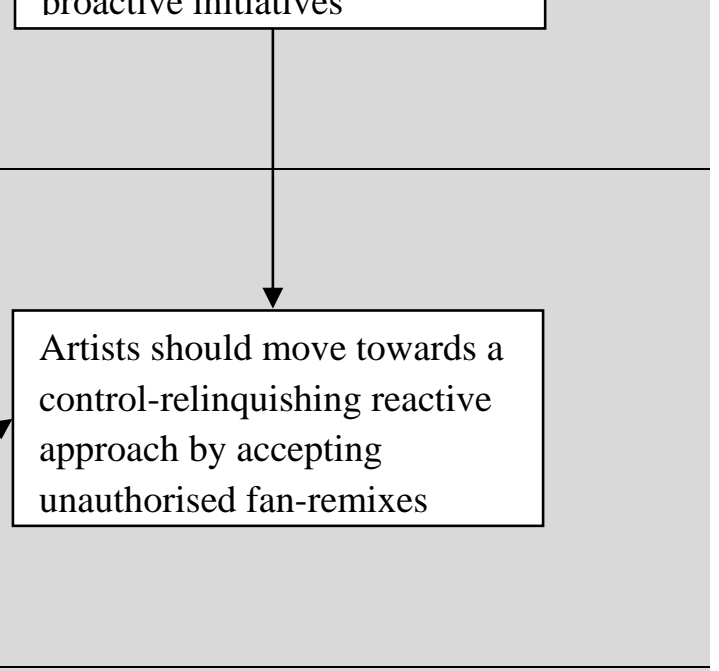

Artists should ensure that

campaigns are genuine and

sincere for them and the fans,

for true creative collaboration

Artists should amalgamate coproduction with other guaranteed lucrative practices to counter-balance instabilitv

Figure 4. Music artist current and recommended approaches to music co-production 




Figure 5. Major label current and recommended approaches to music co-production 
Appendix A Breakdown of interviewees

\begin{tabular}{|c|c|c|c|c|}
\hline $\begin{array}{l}\text { Inter- } \\
\text { view } \\
\text { stage }\end{array}$ & $\begin{array}{l}\text { Inter- } \\
\text { viewee }\end{array}$ & Music industry relevance & Experience & $\begin{array}{l}\text { Geographical } \\
\text { location }\end{array}$ \\
\hline \multirow[t]{17}{*}{$\begin{array}{l}\text { Stage } \\
\text { One }\end{array}$} & S1AB & $\begin{array}{l}\text { Brand Ambassador at crowdfunding } \\
\text { firm }\end{array}$ & 2 years' experience of crowdfunding & New Zealand \\
\hline & S1AC & $\begin{array}{l}\text { Director and Co-founder of } \\
\text { crowdfunding firm }\end{array}$ & 2 years' experience of music crowdfunding & Australia \\
\hline & S1AE & CEO of music firm & 4 years' experience in live streaming interactive experiences & Finland \\
\hline & S1AM & Other music expert & 7 years' experience of various aspects of the music industry & UK \\
\hline & S1AW & Founder of crowdfunding firm & $\begin{array}{l}5 \text { years' experience of crowdfunding and fan-driven A\&R } \\
\text { (ending 2011) }\end{array}$ & USA \\
\hline & S1CS & Music researcher / writer & 3 years' experience writing about music industry & USA \\
\hline & S1DC & $\begin{array}{l}\text { CEO and Founder of crowdfunding } \\
\text { firm }\end{array}$ & 4 years' experience of crowdfunding (ending 2011) & UK \\
\hline & S1EO & $\begin{array}{l}\mathrm{CEO} \text { and Founder of crowdfunding } \\
\text { firm }\end{array}$ & 2 years' experience of live music crowdfunding & Australia \\
\hline & S1EP & Founder of crowdfunding firm & $\begin{array}{l}3 \text { years' experience of crowdfunding and managing a fan-run } \\
\text { online music store (ended unsuccessfully) }\end{array}$ & USA \\
\hline & S1FG & CEO and Founder of music firm & 2 years' experience of fan-driven $A \& R$ & UK \\
\hline & S1GD & $\mathrm{CEO} / \mathrm{Co}$-founder of music firm & 4 years' experience of crowd-chosen songs at public places & USA \\
\hline & S1GM & Director of music firm & 2 years' experience of offering fans shares in festival & UK \\
\hline & S1IL & Co-founder of crowdfunding firm & 2 years' experience of crowdfunding & USA \\
\hline & S1JF & CEO of music firm & $\begin{array}{l}4 \text { years' experience of offering "groovies" when fans socially } \\
\text { share to earn streams }\end{array}$ & USA \\
\hline & S1JP & $\begin{array}{l}\text { Founder and CEO of crowdfunding } \\
\text { firm }\end{array}$ & 5 years' experience of crowdfunding & USA \\
\hline & S1JY & $\begin{array}{l}\text { CEO and Co-Founder of } \\
\text { crowdfunding firm }\end{array}$ & 4 years' experience of crowdfunding & Canada \\
\hline & S1MD & $\begin{array}{l}\text { Managing Director of crowdfunding } \\
\text { firm }\end{array}$ & $\begin{array}{l}5 \text { years' experience of crowdfunding and offering a direct-to-fan } \\
\text { platform for artists }\end{array}$ & UK \\
\hline
\end{tabular}




\begin{tabular}{|c|c|c|c|c|}
\hline & S1MK & Other music expert & $\begin{array}{l}15 \text { years' experience of involving their fans (including } \\
\text { crowdfunding) }\end{array}$ & UK \\
\hline & S1MM & Music researcher / writer & 3 years' experience writing about music industry music & UK \\
\hline & $\mathrm{S} 1 \mathrm{MP}$ & $\begin{array}{l}\text { CEO and Founder of crowdfunding } \\
\text { firm }\end{array}$ & 3 years' experience of crowdfunded tours & USA \\
\hline & S1MR & CEO/Co-Founder of music firm & 3 years' experience of interactive marketing & USA \\
\hline & S1OL & $\mathrm{CEO}$ of music firm & 3 years' experience of crowd-sourced concert footage editing & USA \\
\hline & S1PA & CEO and Founder of music firm & 4 years' experience of consumers licensing soundtracks & USA \\
\hline & S1PS & Co-Founder of music firm & $\begin{array}{l}2 \text { years' experience as a fan-run record label (ended } \\
\text { unsuccessfully) }\end{array}$ & Denmark \\
\hline & S1RA & President/Founder of music firm & 7 years' experience of a fan-run record label & USA \\
\hline & $\mathrm{S} 1 \mathrm{RC}$ & $\begin{array}{l}\text { Creator and Producer at } \\
\text { crowdfunding firm }\end{array}$ & 2 years' experience of crowdfunding & USA \\
\hline & S1RG & Co-founder of crowdfunding firm & 3 years' experience of live music crowdfunding & Australia \\
\hline & S1RM & Founder of crowdfunding firm & 5 years' experience of music crowdfunding & Canada \\
\hline & S1RT & $\mathrm{CCO}$ of music firm & 5 years' experience of interactive music creation apps & UK \\
\hline & $\mathrm{S} 1 \mathrm{TH}$ & Senior Consultant at music firm & $\begin{array}{l}3 \text { years' experience at working with a major record label on } \\
\text { consumer insight }\end{array}$ & UK \\
\hline & S1TS & $\begin{array}{l}\text { Head of Interactive Marketing Team } \\
\text { at music firm }\end{array}$ & 4 years' experience of fan interaction marketing & USA \\
\hline & S1TZ & $\begin{array}{l}\text { Operational Project Manager at } \\
\text { crowdfunding firm }\end{array}$ & 5 years' experience of music crowdfunding & Netherlands \\
\hline & S1VS & $\begin{array}{l}\text { Founder and Owner of crowdfunding } \\
\text { firm }\end{array}$ & 1 year's experience of crowdfunding & USA \\
\hline & S1WS & Other music expert & 5 years' experience of various aspects of the music industry & Germany \\
\hline Stage & S2AK & Director of artist management firm & 3 years' experience & UK \\
\hline Two & S2AS & $\begin{array}{l}\text { Vice President - Global Digital } \\
\text { Business Development at a major } \\
\text { label }\end{array}$ & 8 years' experience & UK \\
\hline & $\mathrm{S} 2 \mathrm{FB}$ & $\begin{array}{l}\text { Vice President - Marketing Services } \\
\text { at a major record label }\end{array}$ & 6 years' experience & UK \\
\hline & $\mathrm{S} 2 \mathrm{JH}$ & $\begin{array}{l}\text { Director - Global Digital Business at } \\
\text { a major record label }\end{array}$ & 8 years' experience & UK \\
\hline
\end{tabular}




\begin{tabular}{|c|c|c|c|c|}
\hline & $\mathrm{S} 2 \mathrm{JJ}$ & $\begin{array}{l}\text { Founder and CEO of artist } \\
\text { management company }\end{array}$ & 22 years' experience & UK \\
\hline & S2JM & $\begin{array}{l}\text { Senior Vice President - Legal \& } \\
\text { Business Affairs at a major label }\end{array}$ & 18 years' experience & UK \\
\hline & $\mathrm{S} 2 \mathrm{JT}$ & $\begin{array}{l}\text { Twenty years' experience of various } \\
\text { areas of music industry including } \\
\text { artist management }\end{array}$ & 20 years' experience & USA \\
\hline & $\mathrm{S} 2 \mathrm{JW}$ & $\begin{array}{l}\text { CEO of company that represents } \\
\text { artist managers }\end{array}$ & 14 years' experience & UK \\
\hline & $\mathrm{S} 2 \mathrm{KS}$ & $\begin{array}{l}\text { Head of Third Party Label Services } \\
\text { at a major label }\end{array}$ & 5 years' experience & UK \\
\hline & $\mathrm{S} 2 \mathrm{NP}$ & $\begin{array}{l}\text { Director of artist management } \\
\text { company }\end{array}$ & 8 years' experience & UK \\
\hline Stage & S1AM & Other music expert & 7 years' experience of various aspects of the music industry & UK \\
\hline Three & S1CS & Music researcher / writer & 3 years' experience writing about music industry & USA \\
\hline & S1FG & CEO and Founder of music firm & 2 years' experience of fan-driven $A \& R$ & UK \\
\hline & S1JF & CEO of music firm & $\begin{array}{l}4 \text { years' experience of offering "groovies" when fans socially } \\
\text { share to earn streams }\end{array}$ & USA \\
\hline & S1MK & Other music expert & $\begin{array}{l}15 \text { years' experience of involving their fans (including } \\
\text { crowdfunding) }\end{array}$ & UK \\
\hline & S1PA & CEO and Founder of music firm & 4 years' experience of consumers licensing soundtracks & USA \\
\hline & S1PS & Co-Founder of music firm & $\begin{array}{l}2 \text { years' experience as a fan-run record label (ended } \\
\text { unsuccessfully) }\end{array}$ & Denmark \\
\hline & S1RG & Co-founder of crowdfunding firm & 3 years' experience of live music crowdfunding & Australia \\
\hline
\end{tabular}




\section{Appendix B Interview questions}

1. To what extent would you say that music consumers are becoming involved or integrated into the business or creative side of music production?

2. What would you say have been the management effects of music co-production for the music industry?

3. Are you aware of any consumer-driven co-production activities that have affected music artists or labels - either positively or negatively?

4. Are you aware of any industry-driven co-production activities that have affected music artists or labels - either positively or negatively?

5. Regarding co-creation of music content with the fans, do you believe that consumers can realistically contribute to the creative process and how would this affect the artists in terms of music content, careers and fan relationships?

6. How would you rate the willingness of the major labels to experiment with co-production, and how might this affect their control of content?

7. To what extent would you say that the consumer role within the music industry is changing due to co-production, and in what way is it developing?

8. How are artists and/or labels approaching the prospect of embracing (or even driving) coproduction for their present or future activities?

9. How do you think that co-production between the consumer and artist will impact upon future business practices for industry professionals? 